\title{
UK Renal Registry 15th Annual Report: Appendix G UK Renal Registry Dataset Specification
}

This appendix is available on the UK Renal Registry website only. The current version of this document can be found under the downloads menu at www.renalreg.com.

\section{KARGER}

Fax +41 613061234

E-Mail karger@karger.ch

www.karger.com
UK Renal Registry, Southmead Hospital, Southmead Road, Bristol, BS10 5NB, UK

Email: renalregistry@renalregistry.nhs.uk 